\title{
$\begin{array}{lllllllll}\mathrm{I} & \mathrm{N} & \mathrm{S} & \mathrm{T} & \mathrm{I} & \mathrm{T} & \mathrm{U} & \mathrm{T} & \mathrm{E}\end{array}$
}

\section{Urban and Rural Children Experience Similar Rates of Low-Income and Poverty}

B Y ALLISON CHURILLA

$\mathrm{I}$ n 2006, nearly 5 million children in rural America and more than 9 million children in central cities lived in a family with incomes less than twice the federal poverty level. ${ }^{1}$ In 2006 , the federal poverty level for a family of four was $\$ 20,000$. Researchers and policy analysts estimate that a family of this size would need an annual family income of at least $\$ 40,000$, or twice the federal poverty level, to meet its basic needs. ${ }^{2}$ Families with earnings that fall below this level are "low income."

Although the number of low-income children is higher in urban America, as a share of the population, their rate of low income is similar in both rural areas and central cities. In 2006, nearly one half of all children in both areas lived in a low-income family. This stands in sharp contrast to children in suburban areas, where only 29 percent lived in low-income households.

During the past 15 years, rates of both child poverty and low income in central cities and rural communities have been converging as poverty has eased in central cities. While there have been small to moderate changes in rural rates of child poverty and in low income during the last 15 years, the overall decline is much smaller than what has taken place in central cities since 1991. In striking contrast, suburban children experience much lower rates of poverty.

This brief highlights characteristics associated with economic insecurity in these rural communities and central cities. Analyses find some similarities in the characteristics of low-income children and their parents in rural areas and central cities, but the converging fortunes of families are largely attributable to declining rates of low income among children in central cities.

Racial and Ethnic Minority Children at Elevated Risk for Economic Insecurity in Both Rural Areas and Central Cities

In 2006, there were more than 3 million low-income, white children living in rural areas, or nearly twice the number living in central cities. Central cities were home

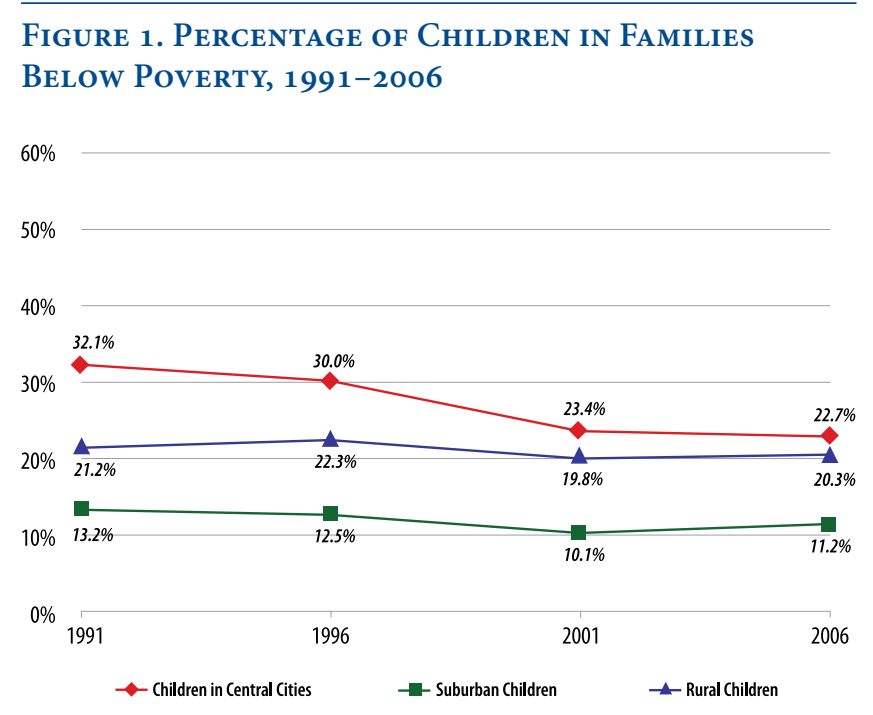

Figure 2. Percentage of Children Living in Low-InCOME Families, 1991-2006
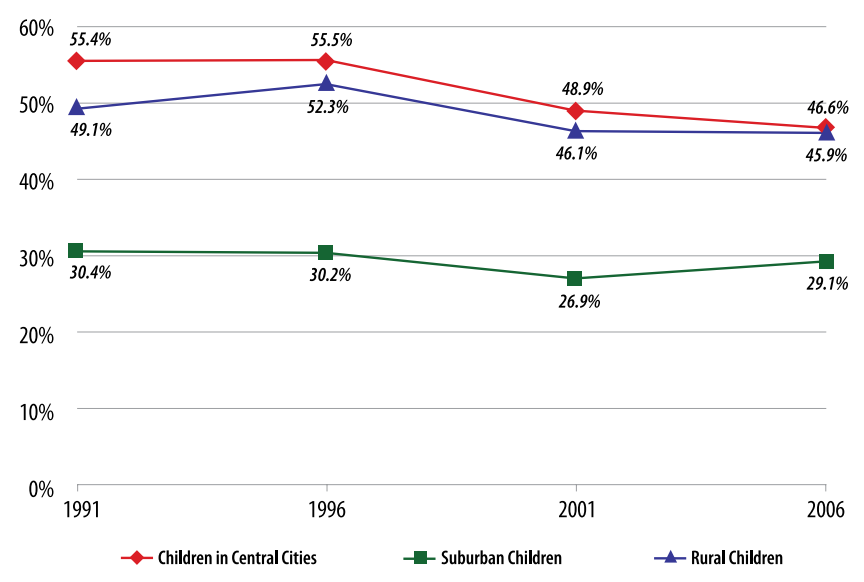

UNIVERSITY of NEW HAMPSHIRE 
TABLE 1.

Percentage

COMPOSITION AND

RATE OF LOW INCOME

BY RACE/ETHNICITY

in Rural Areas

and Central Cities, 2006

\begin{tabular}{l|c|c|c|c}
\hline & \multicolumn{2}{|c|}{ RURAL AREAS } & \multicolumn{2}{c}{ CENTRAL CITIES } \\
\hline & $\begin{array}{c}\text { Percent of Low-Income } \\
\text { Children Who Are: }\end{array}$ & $\begin{array}{c}\text { Rate of Low Income } \\
\text { among: }\end{array}$ & $\begin{array}{c}\text { Percent of Low-Income } \\
\text { Children Who Are: }\end{array}$ & $\begin{array}{c}\text { Rate of Low Income } \\
\text { among: }\end{array}$ \\
\hline White & $61 \%$ & $38 \%$ & $19 \%$ & $25 \%$ \\
\hline Black & $16 \%$ & $69 \%$ & $32 \%$ & $64 \%$ \\
\hline Hispanic/Latino(a) & $15 \%$ & $70 \%$ & $43 \%$ & $63 \%$ \\
\hline Asian & $1 \%$ & $32 \%$ & $4 \%$ & $29 \%$ \\
\hline Other races/ethnicities & $7 \%$ & $65 \%$ & $3 \%$ & $43 \%$ \\
\hline
\end{tabular}

to 1.7 million white low-income children, 3 million black low-income children, and nearly 4 million Hispanic and Latino low-income children. Table 1 translates these numbers into shares of the population (percentages), showing that the largest share of low-income children in rural areas was white in 2006 (61 percent), whereas the largest share of low-income children in central cities was Hispanic or Latino (43 percent). The 65\% "other races/ethnicities" figure likely reflects Native Americans in rural areas.

Even though the racial and ethnic makeup of low-income children in rural areas and central cities differs considerably, children who are racial and ethnic minorities are at greater risk of living at or near the poverty level in both areas of the United States. In rural areas in 2006, most minority children had rates of low income that were nearly twice those of white children. In central cities, rates for minority children were 2.5 times higher than for white children.

\section{Parents' Employment Not a Guarantee against Low-Income}

Although parents' employment is an important factor in determining a family's economic standing, it does not guarantee economic security for children. In rural areas and central cities, a majority of low-income children had at least one parent who was employed full-time (60 percent in rural areas and 59 percent in central cities). Another 19 percent of children in both areas had at least one parent who was employed part-time or part-year in 2006-one-third of whom said they worked part-time because of slack work conditions or a lack of full-time work opportunities. ${ }^{3}$

Thus, nearly 80 percent of low-income children in both rural areas and central cities had at least one working parent in 2006. What, then, explains the persistence of low income? One reason is that many low-income, full-time working parents are employed in service occupations, which tend to offer low wages and few benefits, and in occupations that are sensitive to seasonal cycles. Table 2 shows the top five occupations employing low-income, full-time working parents in both areas.

The median hourly wage was $\$ 13.99$ for all full-time workers in rural areas and $\$ 16.54$ for full-time workers in central cities in 2006. This means that, on average, rural full-time workers earn approximately $\$ 100$ less per week than their counterparts in urban cores and $\$ 5,000$ less annually. ${ }^{4}$ Lower average wages may be one factor that makes poverty and low income more persistent in rural communities.
TABLE 2.

Top Five Occupations EMPLOYING LOW-INCOME, Full-Time WORKING Parents in Rural Areas and Central Cities, 2006

\begin{tabular}{|c|c|c|}
\hline & Percent Employed in 0ccupation & Median Hourly Wage \\
\hline \multicolumn{3}{|l|}{ Rural Low-Income Parents } \\
\hline 1 Truck and other drivers & 4 & $\$ 13.46$ \\
\hline 2 Miscellaneous agricultural workers & 4 & 8.70 \\
\hline 3 Nursing, psychiatric, and home health aides & 3 & 8.65 \\
\hline $4 \quad$ Managers of retail sales workers & 3 & 11.54 \\
\hline 5 Farmers and ranchers & 2 & 10.99 \\
\hline \multicolumn{3}{|l|}{ Central City Low-Income Parents } \\
\hline 1 Truck and other drivers & 4 & $\$ 14.42$ \\
\hline 2 Construction laborers & 4 & 12.02 \\
\hline 3 Cooks & 3 & 7.69 \\
\hline $4 \quad$ Nursing, psychiatric, and home health aides & 3 & 11.22 \\
\hline $5 \quad$ Maids and housekeepers/cleaners & 3 & 8.65 \\
\hline
\end{tabular}

Note: Median hourly wage is for all full-time workers employed in occupation. 
In both rural areas and central cities, median wages in the top five occupations employing low-income parents fell well below the median hourly wage for all full-time workers in each area. A low-income parent working as a full-time truck driver (among the highest paying fields in the list) would earn about $\$ 1,060$ less per year than the average fulltime worker in rural areas and approximately $\$ 4,250$ less in central cities.

Further, in both areas, many full-time, low-income working parents are employed in personal care and service occupations in the health and leisure industries. In rural areas and central cities, 3 percent of low-income working parents were employed as nursing, psychiatric, and home health aides in 2006. The median wage for low-income working parents in this occupation fell below the full-time median wage by nearly the same amount in rural areas and central cities ( $\$ 5.34$ and $\$ 5.32$, respectively).

Finally, occupations with demand that changes seasonally rank among the jobs with high concentrations of lowincome working parents in rural areas and central cities. Two of the top five occupations for low-income working parents in rural areas in 2006 were agriculturally based. Construction ranked among the top five occupations for low-income working parents in central cities. The seasonality of these occupations often means that parents cannot provide their children a steady, year-round income to meet their basic family needs.

\section{Conclusion}

Although there are differences in low-income child populations in rural areas and central cities, there are also strong similarities. In particular, employment-even when it is fulltime-is not a guarantee of economic security for families in either area. Recent research suggests that weakening labor market conditions will likely hit low-income workers hardest. ${ }^{5}$ These workers already struggle to support their families on low wages that make it difficult to pay for basic necessities such as food, housing, health care, transportation, and child care. Policy analysts advise implementation of a combination of employment and pay equity policies, workforce development policies, public assistance programs, and tax credits to alleviate the pain of economic downturn. $6,7,8$ Such investments can provide a more comprehensive safety net for vulnerable, low-income working parents and their children.

It is also clear that converging rates of poverty and low income are largely due to declining rates of hardship in central cities, rather than to any substantial changes in rural areas since 1991. This implies that rural areas have been less responsive to changes that have benefited lowincome families in central cities. These relatively stagnant rates of poverty and low income in rural areas are a particu- lar challenge to policymakers, reaffirming the unique policy needs of children in these two distinct areas.

\section{Data Used in This Report}

Unless otherwise noted, figures are based on the author's analysis of data from the 2007 Annual Social and Economic Surveys (ASEC) of the Current Population Survey (CPS). The CPS is conducted by the United States Bureau of the Census for the Bureau of Labor Statistics. The ASEC is an annual survey of a nationally representative sample of households and the individuals in those households. Demographic information refers to respondents' characteristics in the year of the survey (2007), while employment and income information refer to the preceding year (2006).

\section{Endnotes}

${ }^{1}$ In this report, "rural" refers to areas classified as nonmetropolitan by the U.S. Office of Management and Budget's (OMB) 2003 metro and nonmetro definitions. "Central cities" are core based statistical areas (CBSA), or counties or groups of counties that contain at least one urban area of 10,000 people. Surrounding counties that are socially or economically integrated with the urban core are also included in the CBSA. "Suburban areas" are those areas that are a balance of a CBSA and a nonmetropolitan area. There were changes to the definition of metroploitan and non-metropolitan between the survey years of 2003 and 2004. For more information on OMB classifications, see http://www.ers.usda.gov/briefing/rurality and http:// www.census.gov/population/www/estimates/00-32997.pdf. Children were excluded from analysis if their families' metropolitan status was coded as "not identifiable" in the ASEC dataset.

${ }^{2}$ Working families typically require earnings that are two to three times the federal poverty level to meet their basic needs, such as housing, food, transportation, child care, and healthcare. (See, for example, the National Center for Children in Poverty (http://www.nccp.org) or the Urban Institute (http://www.urban.org).) Families earning less than twice the federal poverty level are defined as low-income.

3 "Slack work" conditions involve company cutbacks in full-time employment, often forcing employees into involuntary part-time positions.

${ }^{4}$ Calculation is based on the assumption that an average full-time worker engages in 40 hours of work per week for 50 weeks out of the year.

${ }^{5}$ Ridley, Neil, Elizabeth Lower-Basch, and Matt Lewis. 2008. "Low-Income Workers and Families Hardest Hit by Economic Decline Need Help Now." Center for Law and Social Policy (CLASP), Washington, DC.

${ }^{6}$ Boushey, Heather, Chauna Brocht, Bethney Gundersen, and Jared Bernstein. 2001. Hardships in America: The Real Story of Working Families. Washington, DC: Economic Policy Institute.

${ }^{7}$ Parrott, Sharon, Isaac Shapiro, and John Springer. 2005. "Selected Research Findings on Accomplishments of the Safety Net." Center on Budget and Policy Priorities (CBPP), Washington, DC.

${ }^{8}$ Lower-Basch, Elizabeth. 2008. "Tax Credits and Public Benefits: Complementary Approaches to Supporting Low-Income Families." Center for Law and Social Policy (CLASP), Washington, DC. 


\section{CARSEY INSTITUTE}

\section{Author}

Allison Churilla is a Policy Fellow at the Carsey Institute and a Ph.D. candidate in the Department of Sociology at the University of New Hampshire (allison.churilla@unh.edu).

\section{Acknowledgements}

The author would like to thank Cynthia M. Duncan, Curt Grimm, Daniel Lichter, William P. O'Hare, Barbara Ray, Jennifer Sherman, Kristin Smith, Amy Sterndale, Ann Tickamyer, and Sally Ward for their assistance and comments on earlier versions of this brief.

\section{CARSEY

Building knowledge for families and communities

The Carsey Institute at the University of New Hampshire conducts independent, interdisciplinary research and communicates its findings to policymakers, practitioners and the general public.

Huddleston Hall

73 Main Street

Durham, NH 03824

(603) 862-2821

www.carseyinstitute.unh.edu

The Carsey Institute Reports on Rural America are supported by the Annie E. Casey Foundation's initiative to strengthen rural families, the Ford Foundation, and by the W.K. Kellogg Foundation. 